\title{
Anatomical investigations of the strawberry (Fragaria grandiflora Ehrh.) receptacle in the initial stages of development
}

\author{
JAN SZYMANSKI
}

\begin{abstract}
Research Institute of Vegetable Crops, ul. 22 Lipca 1/3, 96-100 Skierniewice, Poland
\end{abstract}

(Received: January 14, 1980)

\begin{abstract}
The anatomical changes occurring in the strawberry fruit in the course of its growth were investigated. Flowers or fruits were collected from the apexes of the inflorescence of plants of the cultivar 'Talisman' cultivated in the glasshouse under long day. A method was developed for embedding the receptacle in a mixture of paraffin, rubber and wax, because the classical paraffin method did not give good results. Three different vascular bundle systems were distinguished in the strawberry, supplying the particular parts of the flower. Most intensive growth of the mean number of cells occurs in the cortex. The number of pith cells, beginning with the 5 th day after pollination does not practically increase. Neither does between the 5 th and 10th day after pollination, the number of cortical cells increase in the apical part of the fruit.
\end{abstract}

\section{INTRODUCTION}

The strawberry is one of the most important fruits cultivated in Europe and America. Poland holds the first place in Europe and the second in the world as regards strawberry production.

A good knowledge of the structure and function of this plant, and particularly its edible part facilitates breeding work and economic exploitation.

The strawberry receptacle called a pseudoberry is referred to by pomologists as fruit ( $\mathrm{P}$ i e $\mathrm{n}$ i ą $\dot{z} \mathrm{ek}, 1976$ ). The main tissues forming the receptacle are the cortex and pith, at the boundary between them lie the vascular bundles (part of them are also present in the cortex).

$\mathrm{H}$ a vis (1943) found that the cortex in the strawberry fruit grows faster than the pith and also faster than the fruit as a whole, but his 
studies were limited solely to cross sections at the widest part of the fruit.

The aim of the present paper was the investigation of the course of growth of the particular tissues and establishment of the number and dimensions of the cells in the young strawberry fruit in its successive developmental stages.

\section{MATERIAL AND METHODS}

The object studied were strawberry fruits of the variety 'Talisman'. The plants were cultivated in the glasshouse throughout the year under daylight of $16-\mathrm{h}$ and 8 -h darkness. For investigations only fruits from the main infructescence peduncle were taken, since it is known that there are distinct differences in chemical composition between the particular fruits in the infructescence. Not all fruits forming on the apical inflorescence of the strawberry develop at the same time. Single fruits on the main axis develop before others ( $\mathrm{Gr}$ a in e $\mathrm{r}, 1956$ ).

Investigations were performed on different-aged fruits $1,5,10$ and 20 days after pollination. In the oldest 20-day fruits the beginning of whitening of the fruit epidermis was noticed as a sign of ripening (N e a l, 1965).

For accurate characterization of the material from each stage the diametre and length of 30 fruits was measured by means of a vernier and then the limit of division tolerance - 95 per cent - was determined for the considered characters ( $\mathrm{E} l \mathrm{and} t, 1964$ ). In this way those fruits were eliminated from the sample for which the values of the characters were higher than the estàblished tolerance limit.

The fruits were cut into three parts: the lower one (a), the middle one (b) and the top one (c) (Fig. 1) and fixed in formalin-acetic acidalcohol fixative (FAA) (J e n s e n, 1962).

The inaterial was embedded in paraffin according to conventional methods, but this did not give satisfactory results. The difficulties in cutting on a microtome strawberries embedded in paraffin are also mentioned by White (1927). This is due to the presence of a large number of calcium oxalate crystals and the high lignification of the vascular bundles as well as the occurrence of hairs saturated with silica on the epidermal surface.

After numerous trials the following procedure was adopted:

1) a normal paraffin mixture (m.p. $52^{\circ}-54^{\circ} \mathrm{C}$ ) with wax $\left(10^{\circ} \%\right.$ ) was prepared - mixture $m-1$. This mixture should be stored in a thermostat for 2 weeks at $60^{\circ} \mathrm{C}$; 
2) mixture $m-2$ was obtained by saturating $m-1$ with caoutchouc rubber. For this purpose a baby sucker is added to mixture $m-1$ after preparation. It is first thinly sliced and immersed in $20 \mathrm{ml}$ of benzene. After $2 \mathrm{~h}$ the whole is poured into the mixture of paraffine and wax. The prepared substance is placed in a thermostat at $60^{\circ} \mathrm{C}$ and after 5 months the mixture is considered to be saturated with rubber;

Fig. 1. Longitudinal section through receptacle: 1 - cortex; 2 - vascular bundles at cortex-pith boundary, $2 \mathrm{a}$ - vascular bundles in cortex; 3 pith; 4 -achene; 5 - base of receptacle; a, b, c

- levels of receptacle cross section

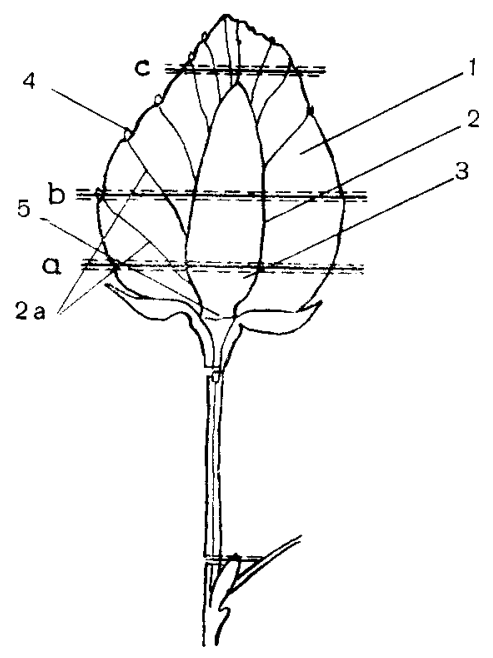

3) mixture $\mathrm{m}-3$ is prepared by mixing equal volumes of $m-1$ and $m-2$ and letting the mixture stand for $24 \mathrm{~h}$ in a thermostat. It is then filtered through folded filter paper, warmed on a water bath for $6 \mathrm{~h}$ at $65^{\circ} \mathrm{C}$ and left to stand in the thermostat for 3 days.

Mixture m-3 is kept in the thermostat until used.

The material was embedded in the above described mixture of paraffin, wax and rubber $(\mathrm{m}-3)$ and then $10-\mu \mathrm{m}$ sections were cut and after deparaffination stained with safranin and fast green.

For examining the course of the vascular bundles in the flower free-hand longitudinal sections were cut and stained with 1 per cent eosin. The receptacle preparations were used for anatomical description and measurements. Photographs and drawings were also made with an Abbe apparatus in order to compare the size of cells from the two stages of fruit development studied, the earliest stage 1 day after pollination and the latest one after 20 days.

On 30 preparations measurements were performed of the largest diametre of the particular cells and their number was counted on cross and longitudinal sections at various levels and developmental stages. 


\section{RESULTS}

The flower of the strawberry 'Talisman' has a highly variable structure, this being connected with the fact that it is an octoploid (alloploid) (S te b b in s, 1958; Ł u cka, 1967). The Fragaria virginiana Duch. and Fragaria chiloensis (L) species from which the strawberry is derived are also octoploids ( $\mathrm{F}$ a d e e v a, 1975).

From among the 150 examined flowers thirty were chosen which exhibited the characteristic pattern with the formula:

$$
\begin{array}{llll}
\mathrm{K}_{5+5} & \mathrm{C}_{5} & \mathrm{~A} \infty \mathrm{G} \infty .
\end{array}
$$

The parts of the flower lie on the flower axis in verticils (Fig. 2).

The vascular bundles in the strawberry flower run in three repetitive systems (Fig. 3):

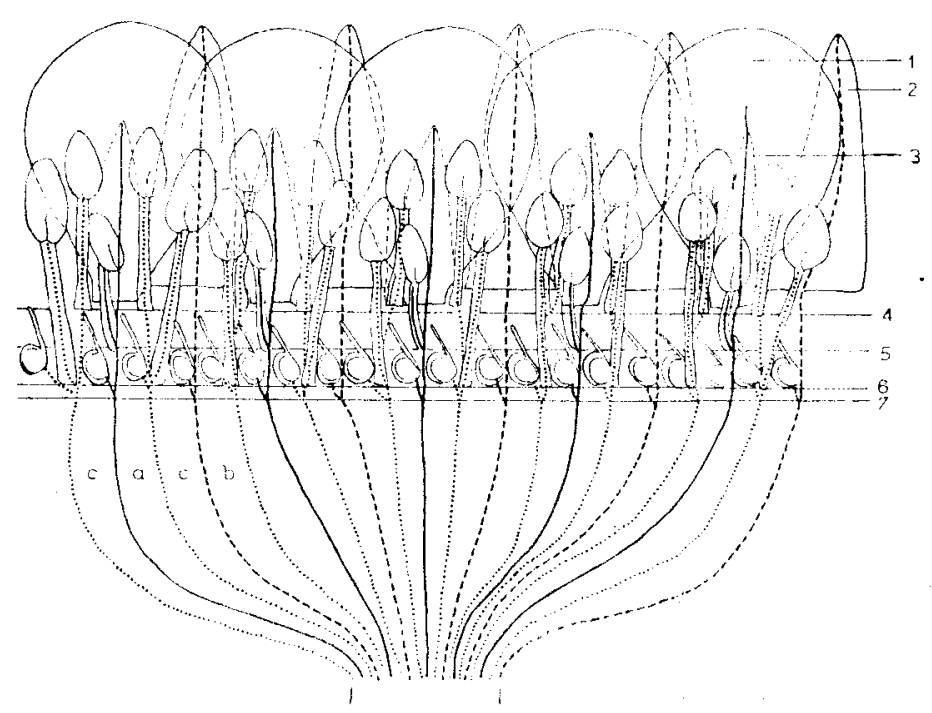

Fig. 2. Diagram of vascular bundles in flower, distributed on one plane: 1 corolla petal; 2-sepal; 3-episepal; 4-outer verticil of androecium; 5-middle verticil of androecium; 6-inner verticil of androecium; 7 -first verticil of pistils; a, b, c-vascular bundles systems

system a - bundles supplying the petals of the corolla, the episepals and stamina of the middle verticel;

system $\mathrm{b}$ - bundles supplying the sepals;

system c - bundles supplying the stamina of the interior and exterior verticils.

All the above mentioned vascular bundles reach the pistils. The 
bundle running to the achene separates into two which run to the walls of the ovary and to the placenta (Fig. 4).

The course of the vascular bundles in the perianth sepals and in one of the corolla petals is shown in Figure 5.

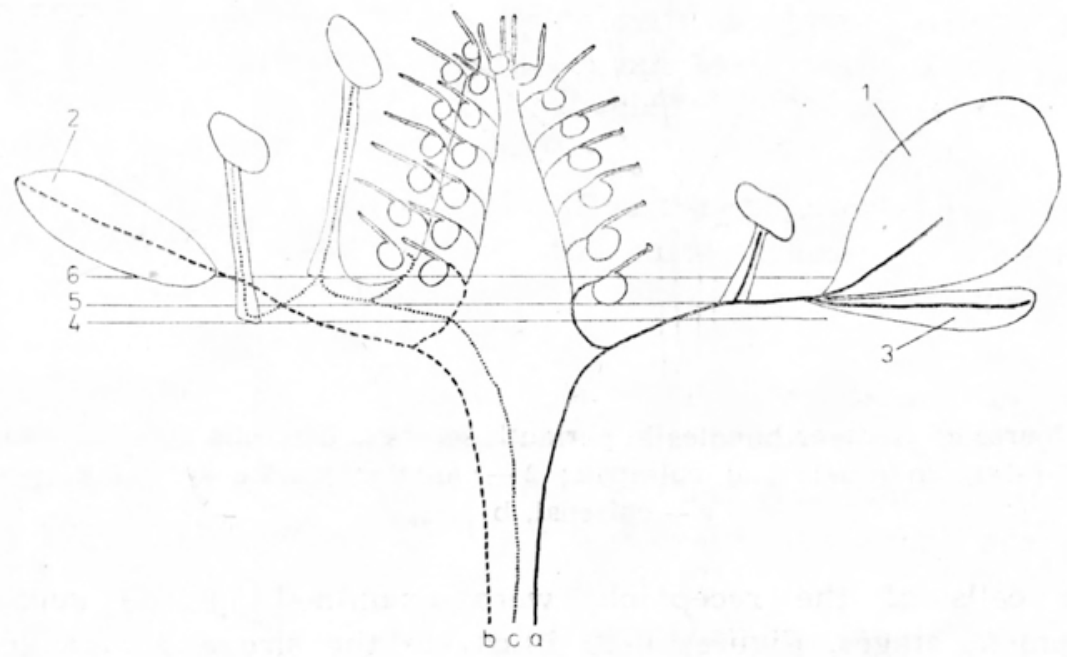

Fig. 3. Vascular bundle system in strawberry flower. Explanations as in Figure 2

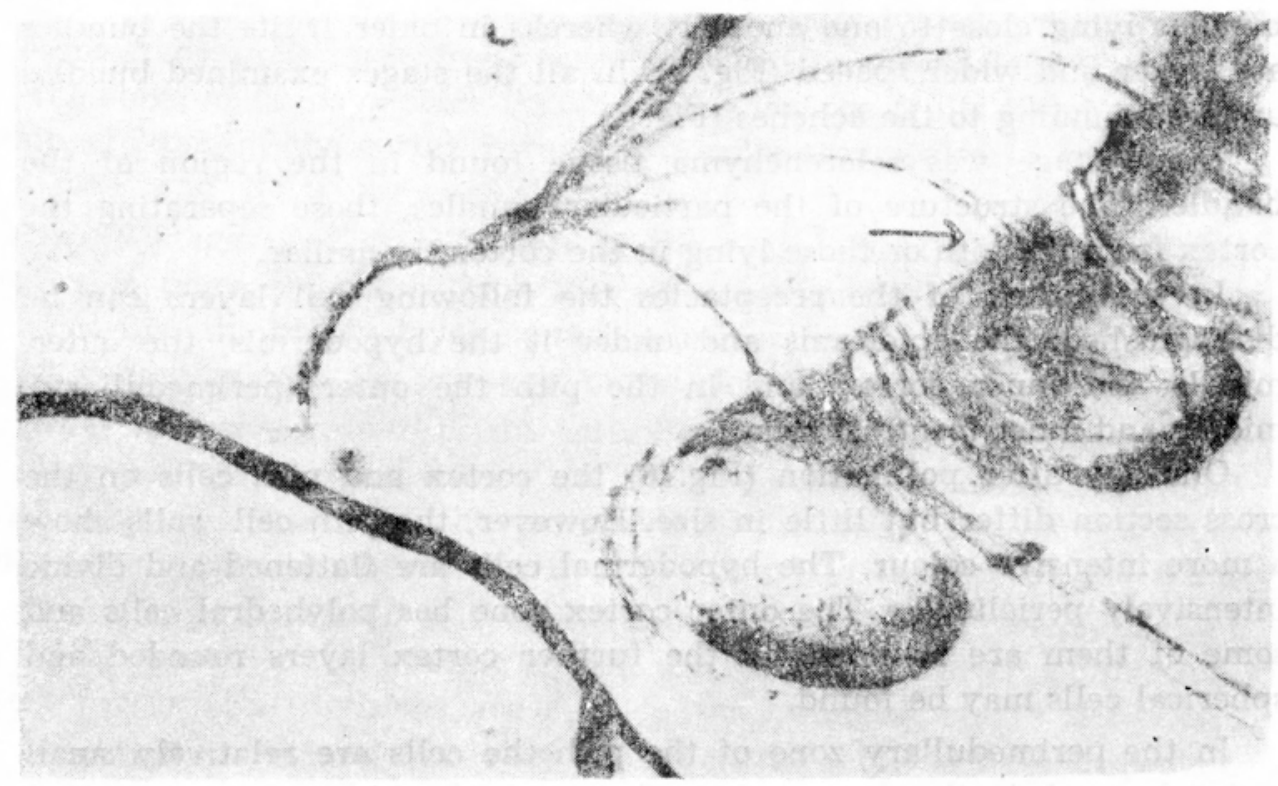

Fig. 4. Fragment of longitudinal section of receptacle, day 1 after pollination with visible vascular bundles reaching to achenes. Forking of vascular bundle close to achene is visible (arrow), $\times 54$. Explanations as in Figure 2 

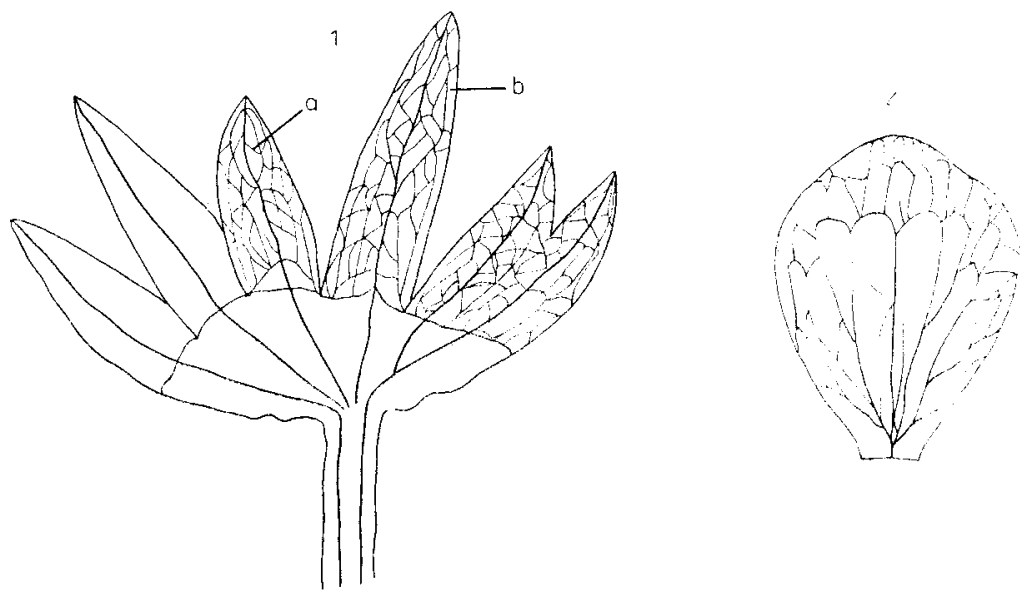

Fig. 5. Course of vascular bundles in perianth sepals and corolla petal: 1 - vascular bundle system in sepals and episepals; 2-vascular bundle system in petal $\times 8$; a - episepal, b- sepal

The cells of the receptacle were examined in the successive development stages. Figures 6-29 illustrate the size and arrangement of the cells.

In the youngest fruits (Fig. 6) the pith is surrounded by vascular bundles lying close to one another, whereas in older fruits the bundles are larger and wider spaced (Fig. 9). In all the stages examined bundles are seen running to the achenes (Fig. 4).

In no stage was sclerenchyma tissue found in the region of the bundles. The structure of the particular bundles, those separating the cortex from the pith or those lying in the cortex, is similar.

In the cortex of the receptacles the following cell layers can be distinguished: the epidermis and under it the hypodermis, the outer, middle and inner cortex, and in the pith the outer (perimedullary), middle and inner (central) zone.

One day after pollination (Fig. 6) the cortex and pith cells on the cross section differ but little in size. However, the pith cell walls show a more intensive colour. The hypodermal cells are flattened and divide intensively periclinally. The outer cortex zone has polyhedral cells and some of them are rounded. In the further cortex layers rounded and spherical cells may be found.

In the perimedullary zone of the pith the cells are relatively small and polygonal, in the deeper zones they are spherical and larger.

At the 5-day stage after pollination the hypodermis consists of 3 cell layers dividing periclinally. The cells of the middle cortex zone are 
larger than the remaining cortex and pith cells (Figs 13, 14, 15). The epidermal cells cease to divide anticlinally and elongate tangentially. Around the vascular bundles there are numerous cells with starch grains, intensively stained with safranin (Fig. 15).

Ten days after pollination the cortex cells elongate greatly in radial direction in the outer and middle zone, but they later become shorter again. The cells of the inner zone are rounded and smaller. Cells with numerous plastids lie around the bundles.

On day 20 of the period after pollination the outer cortex parenchyma grows radially. The middle part of the cortex consists of larger and smaller cells, hence the heteromorphic character of this zone (Figs 17, 19).

Around the vascular budles single cells with plastids may be found, which used to be much more numerous in the preceding stages.

The cells on cross and longitudinal sections from the oldest stage studied (20 days) have distinctly folded walls and there are more numerous intercellular spaces (Figs 17, 19, 24, 25).

At this stage there appears a clear air chamber involving a large part of the pith. The appearance of this chamber as a specific varietal trait (M a rzec et al., 1962) is connected with the occurrence in the cortex and pith of the characteristic cells with folded walls. In the present study both these traits were observed in the variety 'Talisman' at the stage of 20 days after pollination, when the fruits began to turn white (folding of the cortex parenchyma cells occurs also in apple trees $\mathrm{S} \mathrm{mock}$ and Neubert,1950).

In all stages and at all levels of the receptacle the growth of the cortex is more intensive than that of other parts of the fruit. The thickness of the cortex layer increases proportionally to the size of the fruit, beginning with the youngest to the oldest (Fig. 29).

Very intensive growth of the cortex is noticeable between day 1 and 5 after pollination (particularly in the $c$ layer), this being connected with a great increase of the fruit size at this time. In the following successive stages the increment is proportional to the age of the fruit.

In some preparations cell divisions are well visible. The photogram (Fig. 28) shows cells dividing in the cortex 5 days after pollination. Most profuse cell divisions are seen in the youngest stages. However, in all stages cell divsion was observed when the sections were inspected, and this was confirmed when the cells were counted.

The cell counts in the successive stages are shown in Figure 30. A particularly vigorous cell number increase was noted in the cortex, 


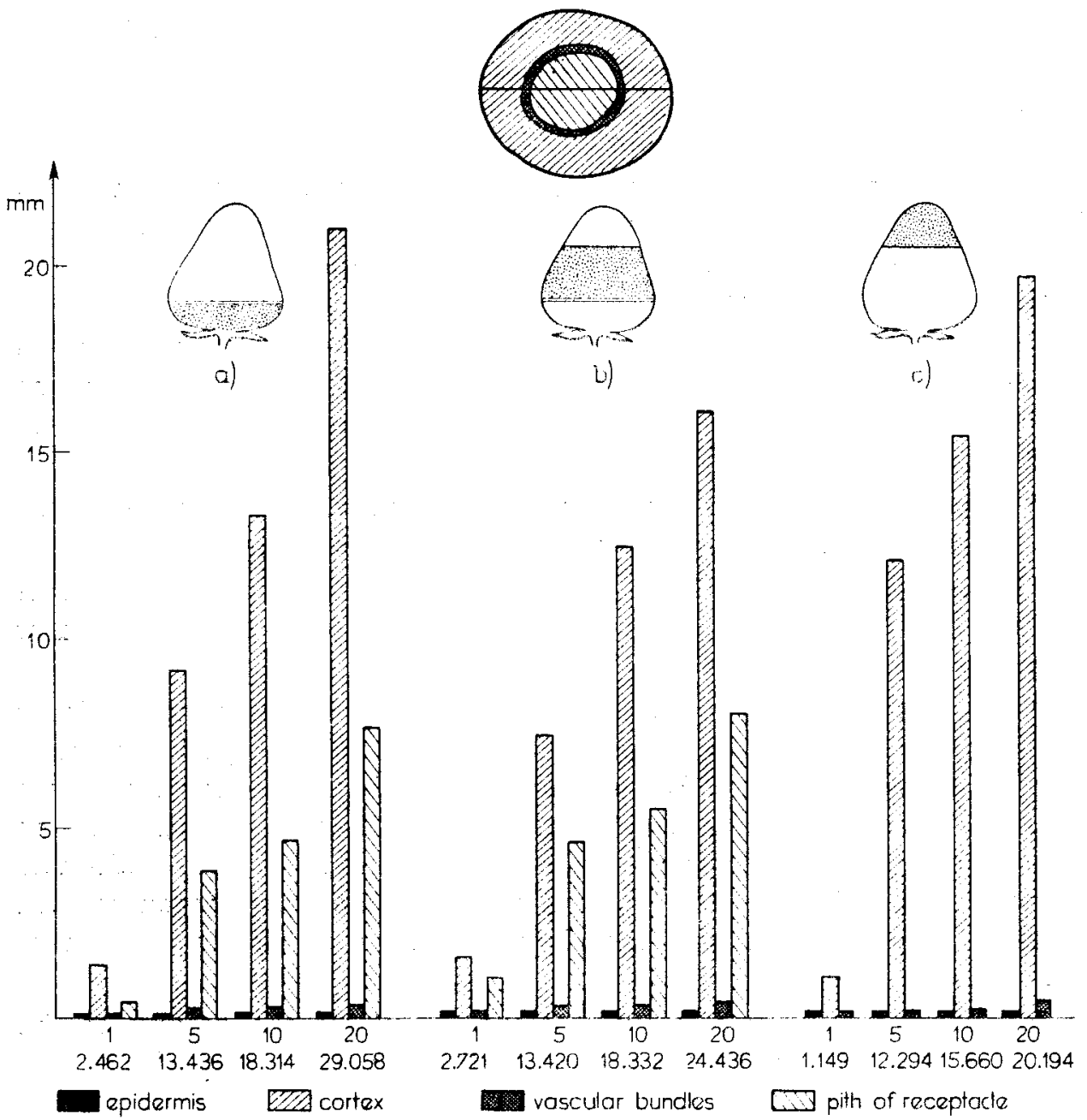

Fig. 29. Width of epidermis and cortex, vascular bundles and pith of receptacle

whereas in the remaining tissues, and especially in the epidermis the number of cells increased much less. The most pronounced changes in the number of cortex cells are noticeable in the apical part and they are smaller in the middle part of receptacle. In general the differences were wider between stages on day 1 and 5 , and 10 and 20 after pollination. The pith cells at level "a" cease to increase in number beginning with day 5 after pollination.

Comparison of the cortex and pith of the fruit as regards cell number, indicates a prevalence of the cortex. This gives grounds to 

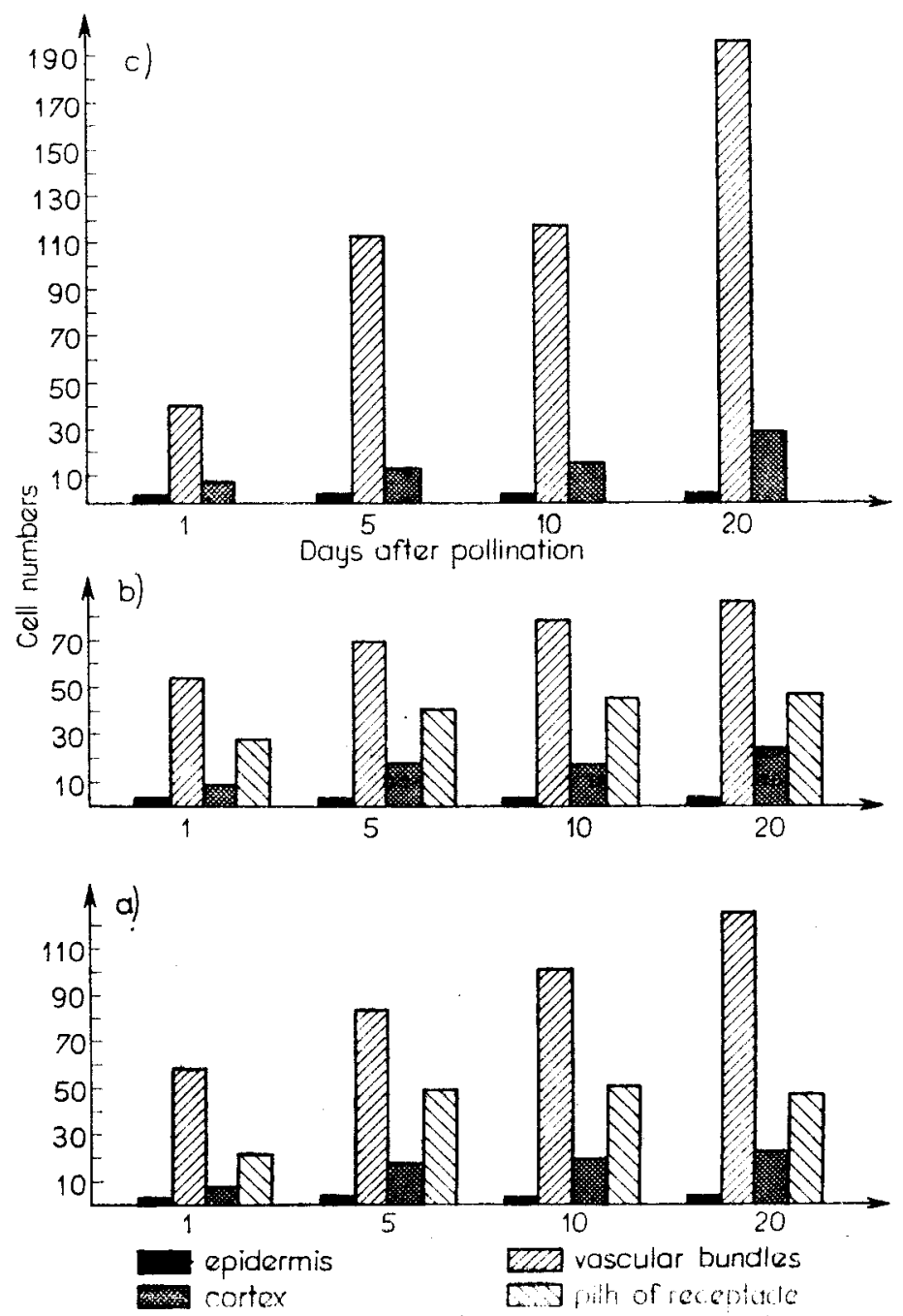

Fig. 30. Mean number of cell on cross section in successive stages of receptacle development. Levels a-c as in Fig. 1

conclusions concerning the specific role of the cortex in fruit growth, as pointed out by $\mathrm{H}$ a $\mathrm{v}$ is (1943).

The cortex parenchyma and pith cells increased greatly in size during fruit development (Table 1). Those of the remaining tissues did not change their dimensions or only slightly. The highest mean values of cell diametre are very large, for the cortex $187.2 \mu \mathrm{m}$ and for the pith $172.8 \mu \mathrm{m}$. 
Table 1

Cell dimension $(\mu \mathrm{m})$ in strawberry receptaculum 0,1 and 5 days after pollination (diameters on cross section from levels $a, b$, and c)

\begin{tabular}{|c|c|c|c|c|c|}
\hline \multirow[t]{2}{*}{ Stage } & \multirow[t]{2}{*}{ Level } & \multicolumn{4}{|c|}{ Tissues } \\
\hline & & epidermis & cortex & $\begin{array}{l}\text { vascular } \\
\text { bundles }\end{array}$ & pith \\
\hline & a & 21.6 & 21.6 & 7.2 & 21.6 \\
\hline \multirow[t]{3}{*}{1} & b & 21.6 & 28.8 & 14.4 & 36.0 \\
\hline & c & 14.4 & 14.4 & $7.2^{2}$ & -1 \\
\hline & a & 28.8 & 115.2 & 14.4 & 79.2 \\
\hline \multirow[t]{3}{*}{5} & $\mathbf{b}$ & 28.8 & 115.2 & 14.4 & 115.2 \\
\hline & c & 28.8 & 50.4 & $7.2^{2}$ & -1 \\
\hline & a & 28.8 & 151.2 & 14.4 & 93.6 \\
\hline \multirow[t]{3}{*}{10} & $\mathrm{~b}$ & 28.8 & 136.8 & 14.4 & 122.4 \\
\hline & c & 28.8 & 93.6 & $7.2^{2}$ & $\ldots 1$ \\
\hline & $\mathbf{a}$ & 28.8 & 194.4 & 14.4 & 165.6 \\
\hline \multirow[t]{2}{*}{20} & b & 28.8 & 172.8 & 14.4 & 172.8 \\
\hline & c & 28.8 & 93.6 & $14.4^{2}$ & -1 \\
\hline
\end{tabular}

1 Measurement beyond central vascular bundle ring.

: Measurement on vascular bundles present in cortex.

\section{DISCUSSION}

The here presented results concerning the course of vascular bundles in the flower of the studied strawberry variety are somewhat similar to those reported by $\mathrm{M}$ a c $\mathrm{D}$ a $\mathrm{n}$ i e 1s (1940). This author calls attention to the fact that the bundles supplying the stamina are fused with those supplying the sepals and petals in the receptacle of Fragaria virginiana Duch. This genus is philogenetically related to the strawberry Fragaria grandiflora Ehrh.

The described system a - vascular bundle supplying a petal of the corolla, the episepals and the shortest stamen (Fig. 3) agrees with the description of $\mathrm{M}$ a c $\mathrm{D}$ an iels (1940). This author, did not, however, distinguish episepals in the perianth. Therefore his supposition would seem correct that in the course of evolution several bundles merged into one. Other vascular systems (b and $c$ ) are described for the first time in the present paper. It is not known, however, whether such systems occur in other strawberry varieties and in the wild species of the genus Fragaria.

The described course of the bundle running to the achene distinctly separates into two vascular traces directed towards the ovary and the placenta (Fig. 4). This suggests a different origin of these elements in agreement with the views of Eames (1961) and Es a u (1973). The 

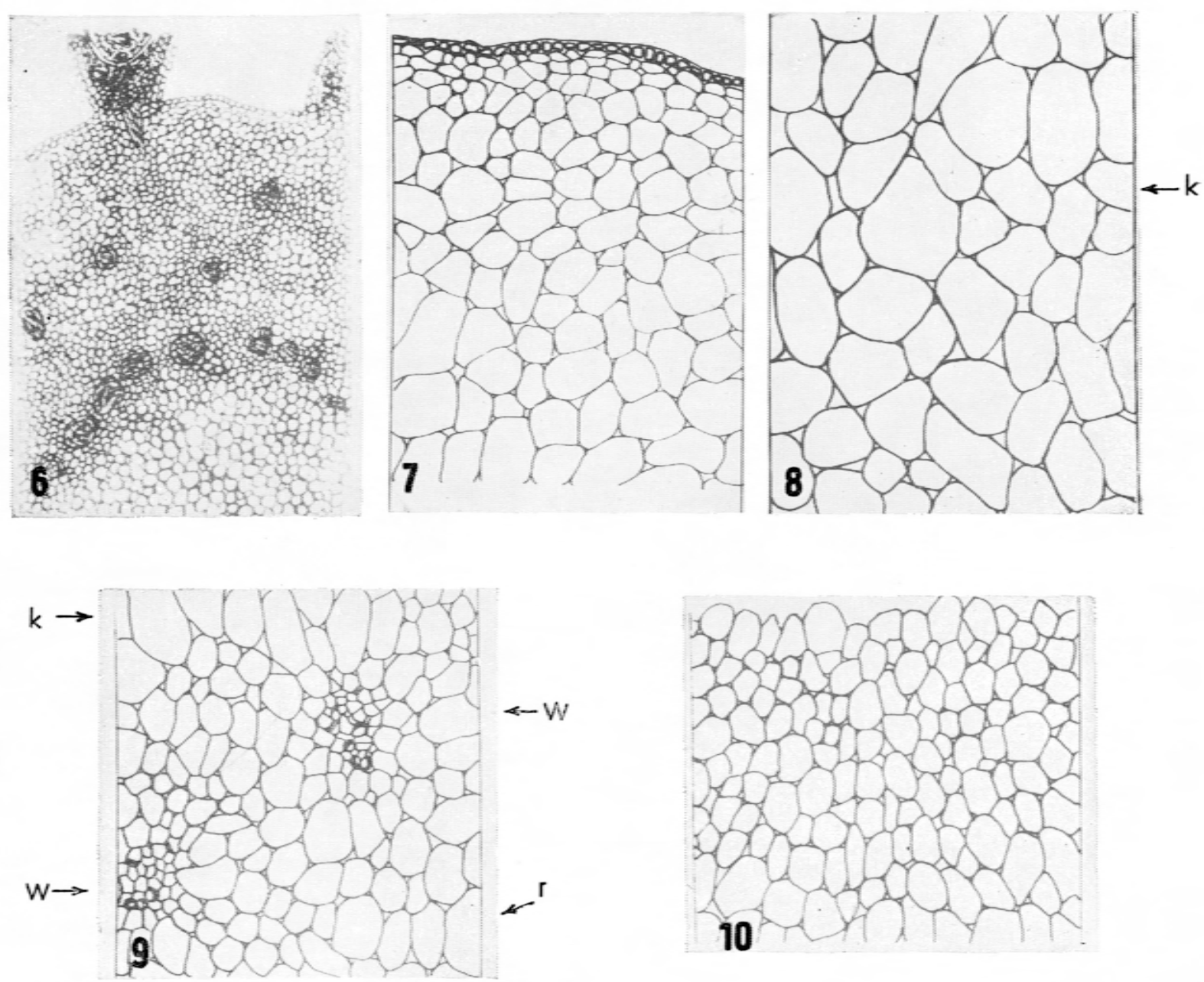

Fig. 6-10. Cross sections of receptacle. Drawing made with the aid of Abbe apparatuss $\times 100$. $\mathrm{K}-$ cortex; $\mathrm{r}-$ pith; wvascular bundles; 6-1 day after pollination; 7-20 days after pollination, epidermis, cortex; 8-20 days after pollination, cortex; 9-20 days after pollination, cortex, vascular bundles, pith; 10-20 days after pollination, pith 

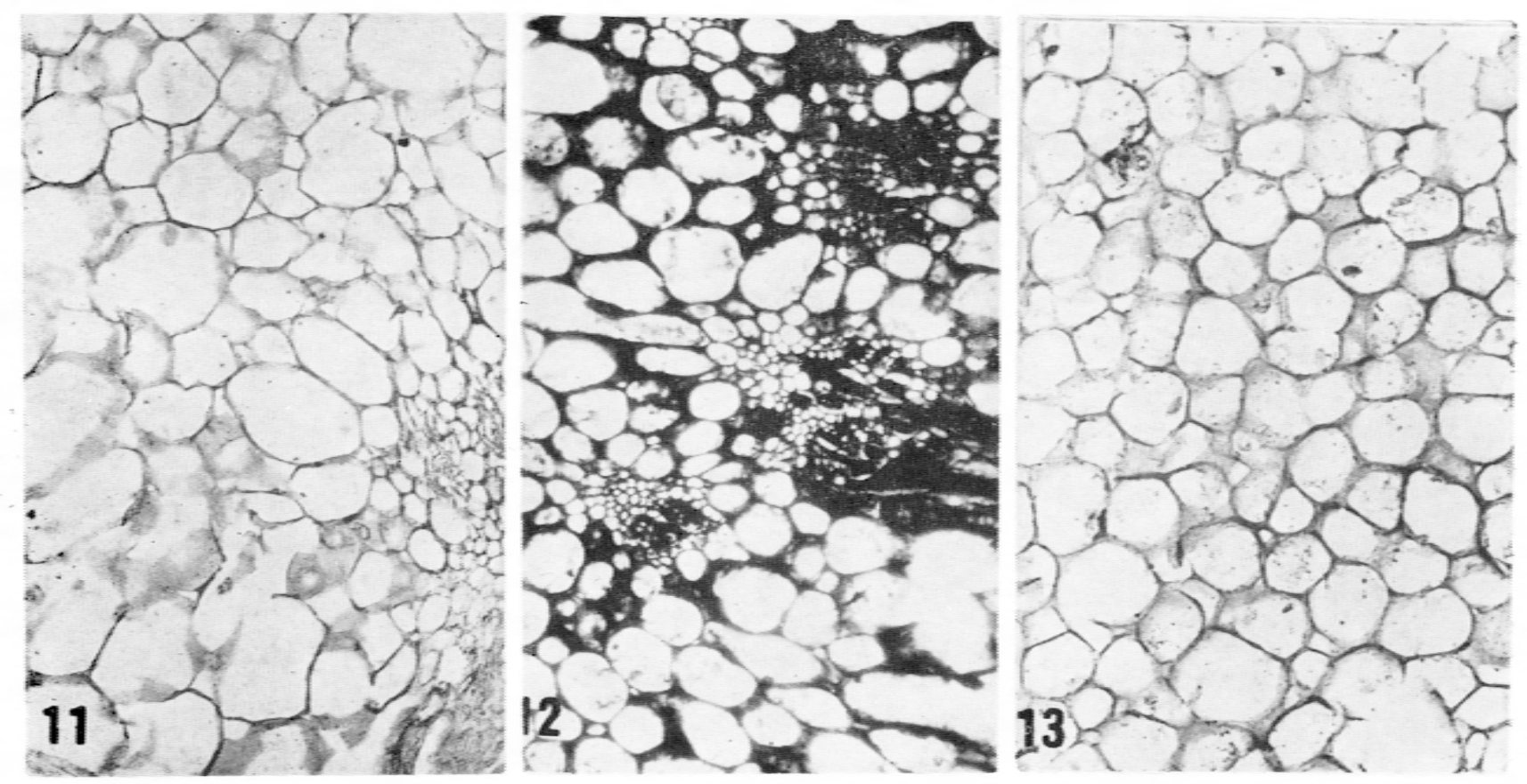

Figs. 11-13. Cells of cortex, vascular bundles and pith of receptacle on cross sections, 5 day after pollination $\times 100$. 11 - cortex, vascular bundle - level a; 12 - cortex, vascular bundles, pith - level a; 13 - pith - level a 

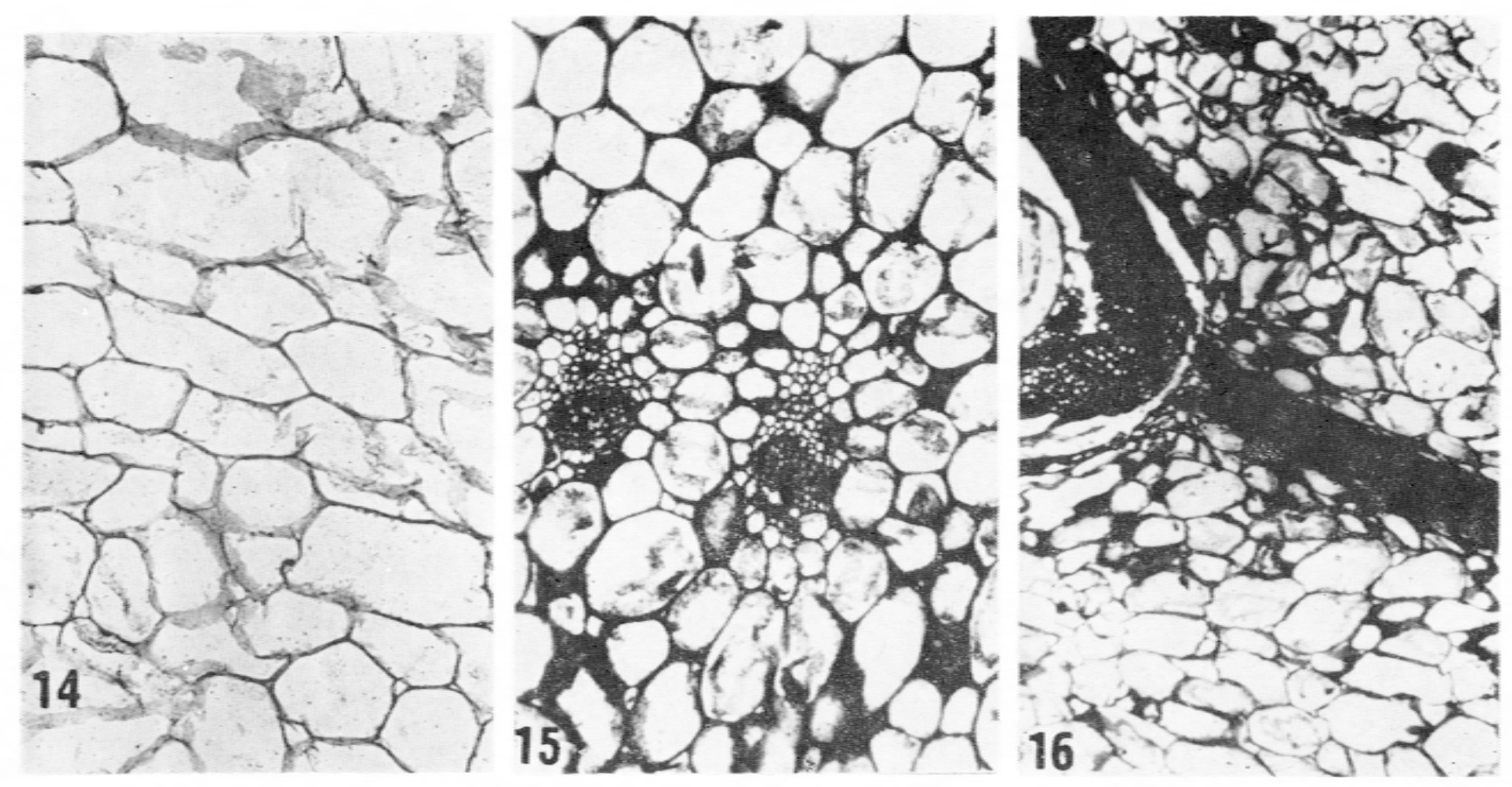

Figs. 14-16. Cells of cortex, vascular bundles and pith of receptacle on cross sections, 5 day after poll1nation $\times 100$. 14 - cortex - level b; 15 - pith, vascular bundles, cortex - level b; 16 - cortex, vascular bundles, achene, level c 

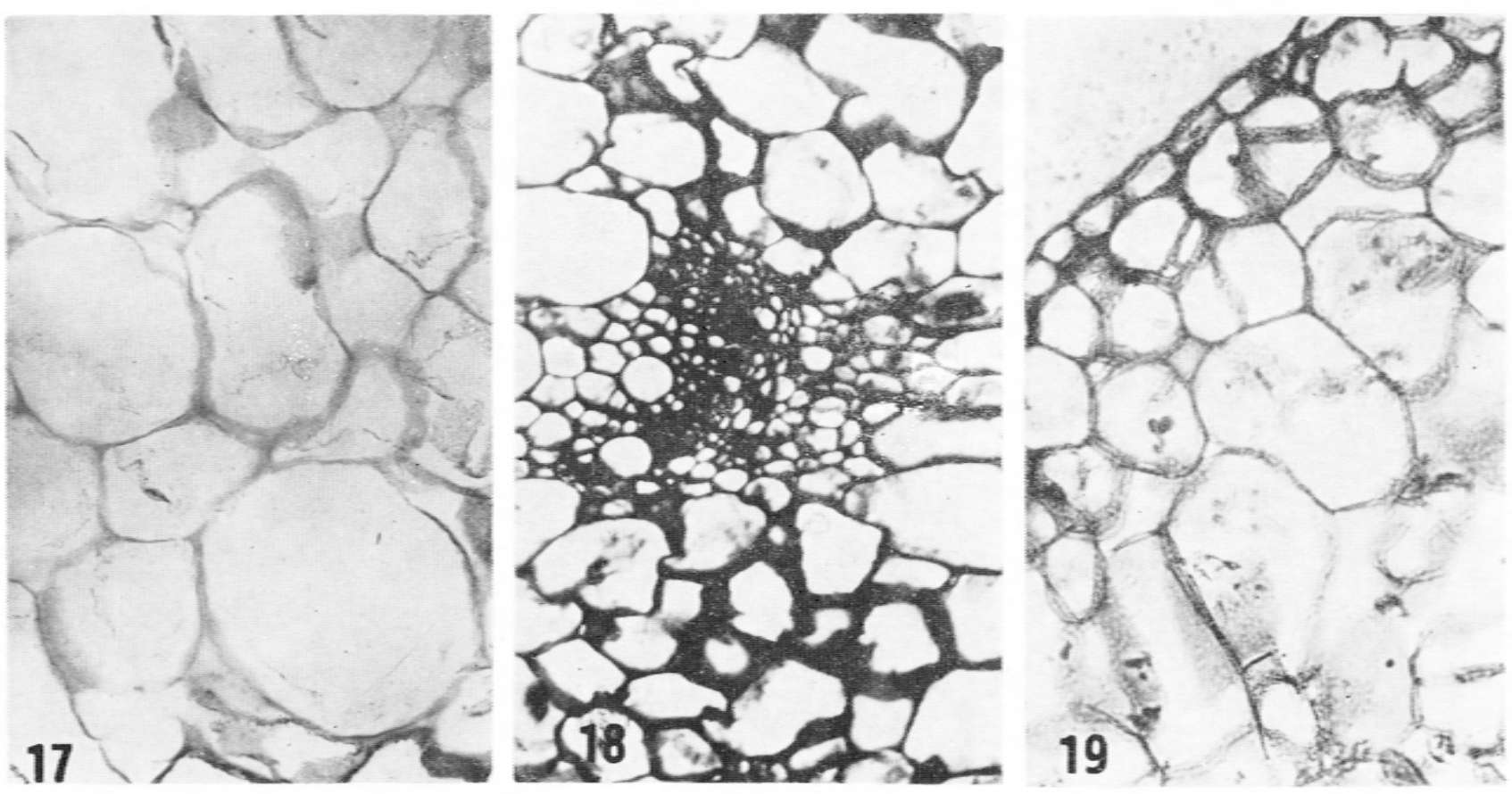

Figs. 17-19. Cells of epidermis, cortex, v. bundles and pith in receptacle on cross section, 20 days after pollination $\times 100.17$ - cortex - level a; 18 - pith, vascular bundles, cortex - level a; 19 - cortex, epidermis — level $\mathrm{b}$ 

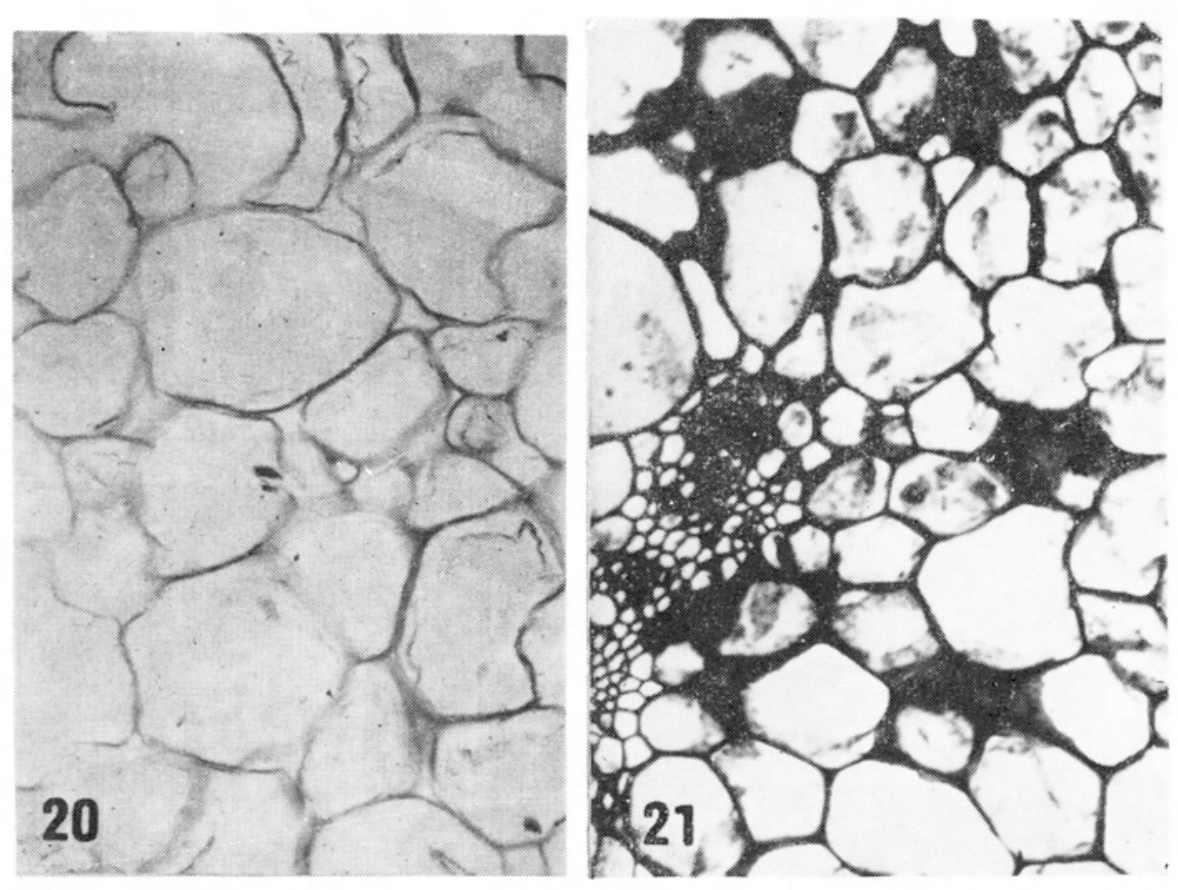

Figs. 20-21. Cells of epidermis, cortex, vascular bundles and pith in receptacle on cross section, 20 days after pollination $\times 100$. 20 - pith - level b; $21-$ cortex, vascular bundles - level c 

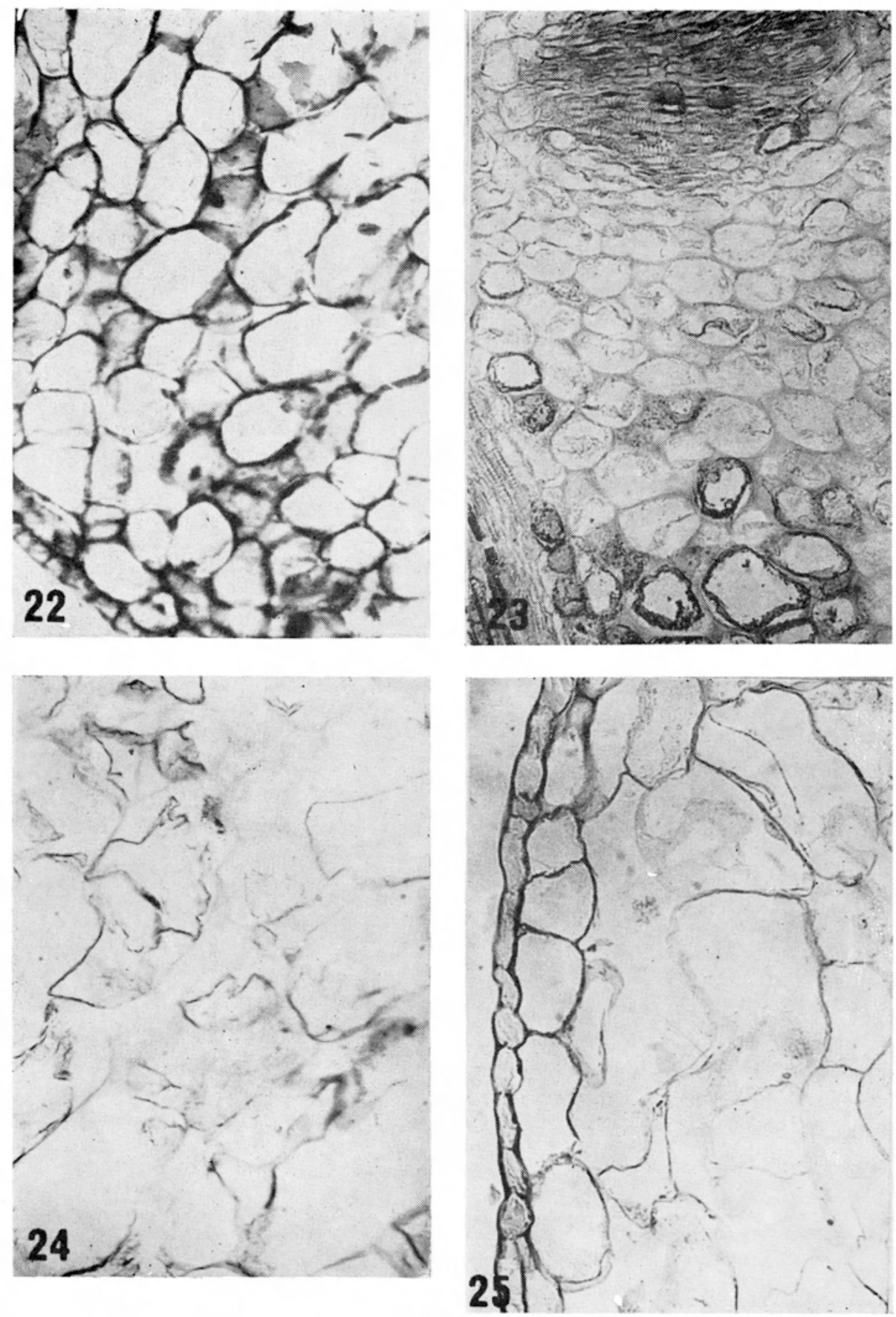

Figs. 22-25. Cells of epidermis, cortex and pith in receptacle on longitudinal section 20 days after pollination $\times 100$. 22 - cortex and epidermis - level a; 23 - pith and fragments of vascular bundles-level a; 24 -pith-level b; 25 - cortex and epidermis - level c 

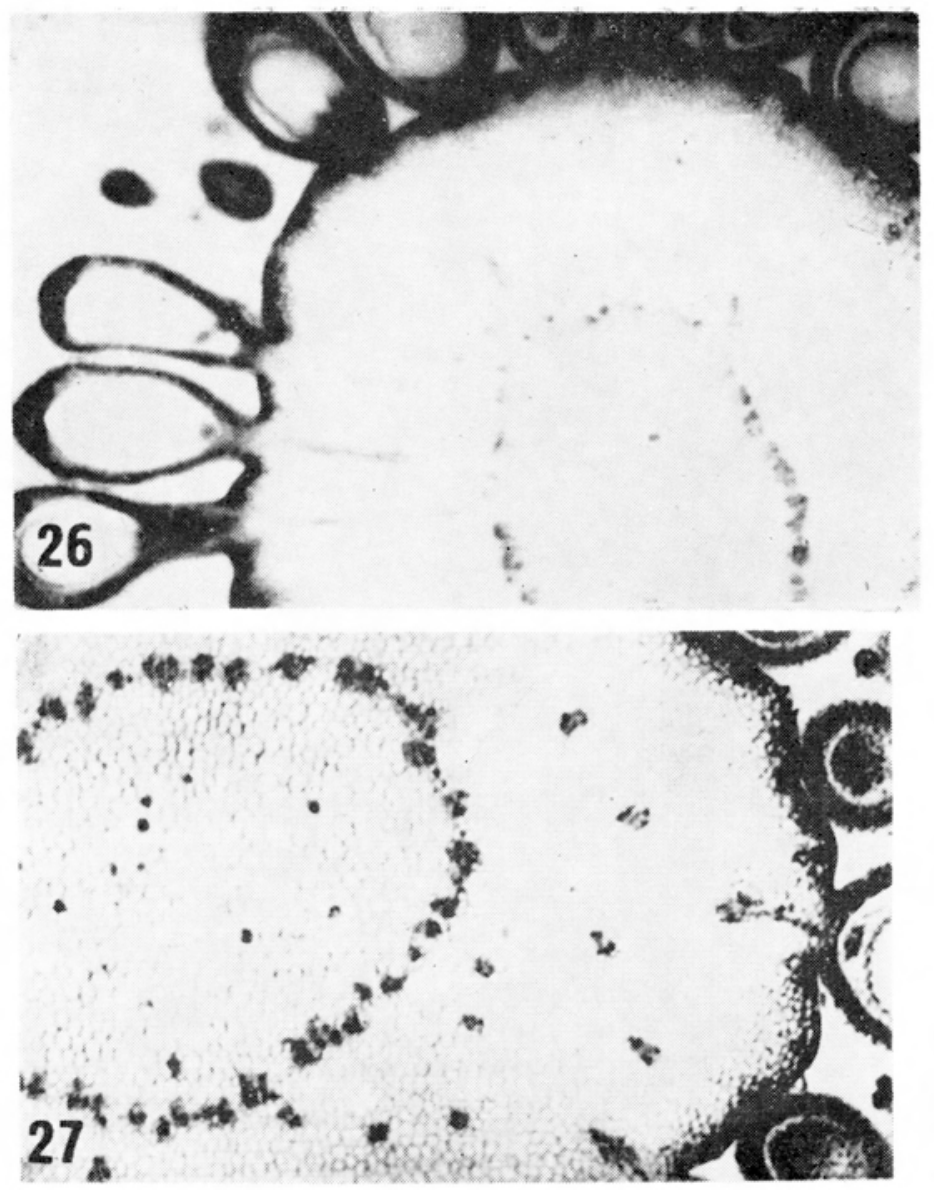

Fig. 26. Receptacie 1 day after pollination, level a, vascular bundle system on cross section $\times 50$

Fig. 27. Receptacle 5 days after pollination, level a, vascular bundle system on cross section, bundles running through cortex to achenes $\times 50$ 


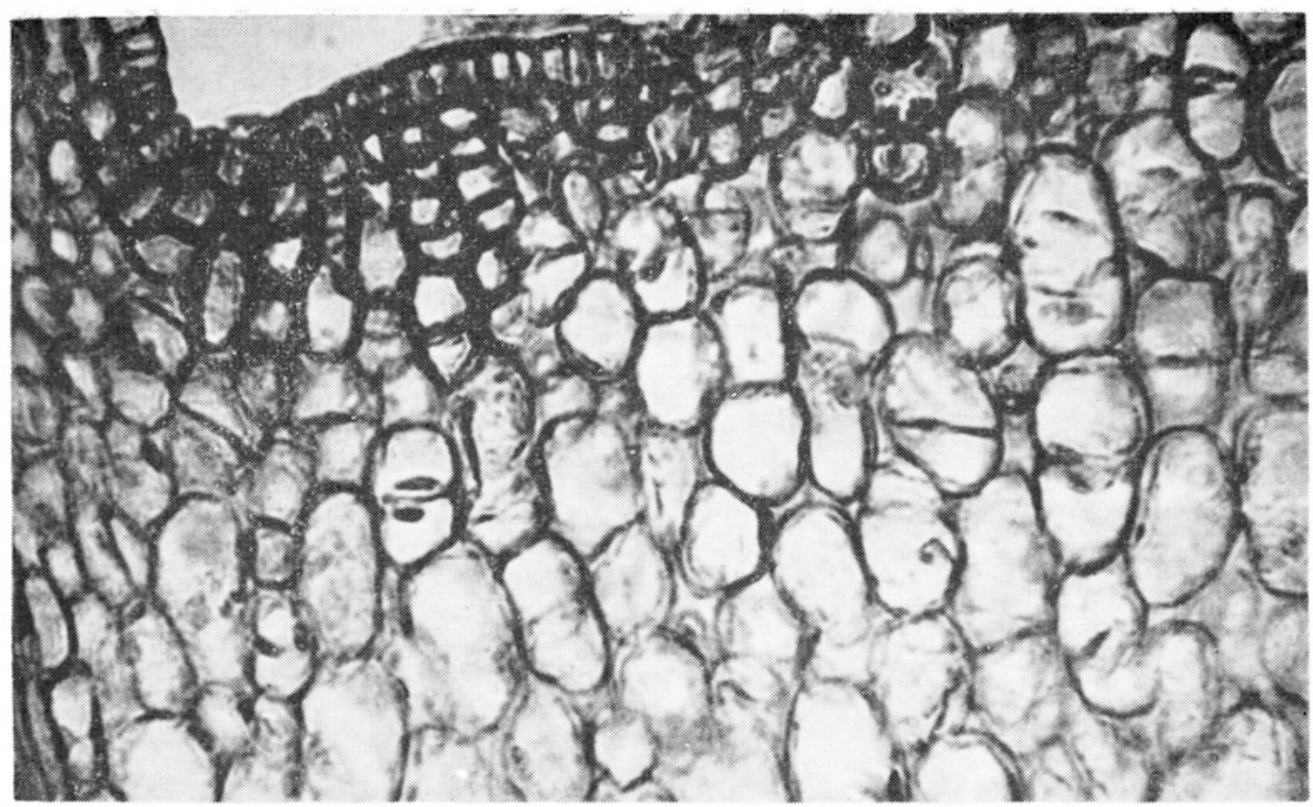

Fig. 28. Epidermis and cortex, vascular bundles and pith of receptacle on cross section 5 days after pollination (level a). Cell divisions are visible $\times 100$ 
growth of the strawberry fruit depends on the increase in the number of cells and their enlargement.

In the present study only the early developmental stages of the receptacle were taken into account. The most advanced stage (20 days after pollination) examined in this paper was called by $\mathrm{Neal}$ (1964) the green-white stage and is the beginning of the ripening process.

In the course of development of the receptacle in the strawberry the cortex grows most intensively. In each of the stages examined and in part of the receptacle cortex growth predominates. The pith grows slower and the epidermis and bundles only slightly.

The number of cortex cells increases uninterruptedly between day $I$ and 20 after pollination. In the particular stages this processes runs as follows:

at the a level - the cell number rises consistently and at the same rate,

at the $b$ level - the cell number increases less than at the preceding level,

at the c level - the cell number increases intensively in two intervals: between day 1 and 5 and 10 and 20 after pollination.

S in nott (1939), investigating the period of development of the pumpkin fruit from setting to ripeness, stressed the primary importance of cell division, he, however, also calls attention to the slow increase of the cell dimensions. Cell divisions cease when the cell reaches a certain threshold size and then the tissue volume growth occurs by enlargement of the cells.

Houghtaling (1935), while investigating the growth of the tomato fruit, Lycopersicum succulentum Mill calls attention to the role of cell division in the early developmental stages. According to this author, the final cell number is determined in the fruit development very early, whereas in Lycopersicum pimpinellifolium (Juslem) Mill. a wild growing species, cell divisions continue up to ripeness of the fruit. Enlargment of the fruit of this tomato occurs not only by cell division, but also be enlargement of the cells.

Investigations on the pumpkin and apple tree fruits indicate the specific role of the cortex in the growth process (S in nott, 1939; $\mathrm{M} \mathrm{a} \mathrm{c} \mathrm{Arthur}$ and Wetmore, 1941).

$\mathrm{Tukey}$ (1974) reports that the cell division phase in apples ends usually several weeks after flowering. Further growth takes place owing to the increase in cell dimensions.

In the growth of stems of the ferm Todea hymenopylloides Rich, et Jess. and in some seed plants such as Datura stramonium L., Pinus 
strobus L., Brassica oleracea var. capitata L. and Brassica oleracea var. caulo rapa DC, the pith plays a dominant role. With development it occupies an ever greater part of the stem. The thickening of the kohlrabi stem is mainly due to the increasing number of pith cells ( $\mathrm{S}$ i n not t, 1936; $\mathrm{H}$ a vis, 1940).

The results of $\mathrm{Havis}$ (1943) conerning the rate of growth of the particular tissues of the strawberry fruit are partly in agreement with data here presented. This author prepared cross sections only of the middle part of the receptaculum which in the present study are denoted as $b$ level. At this level the prevalence of cortex growth over the pith and all the remaining parts of the fruit is distinctly visible. The situation is different at the a and c levels. In the lower part of the fruit, level a, the prevalence of pith growth over that of the cortex is noticeable and so it is as compared with the fruit as a whole. At the apical level c, there is no pith. The epidermal cells only slightly enlarge in the period studied. The outer epidermis cells of the endo- and exocarp in the cucumber increase in size unequally during growth of the fruit. Their dimensions increase in radial direction more than fourfold, whereas their thickness increases but two times ( $\mathrm{Z}$ a $\mathrm{l}$ ę $\mathrm{ska}, 1964)$.

The author is deeply indebted to prof. dr hab. Maria J. Olszewska for her valuable advice and guidance in the course of preparation and writing of this paper and to prof. $d r$ hab. Leszek $S$. Jankiewicz for making his laboratory available to him.

\section{REFERENCES}

E a me s A. J., 1961. Morphology of the angiosperms, Mc Graw Hill Book Company, Inc., New York.

El andt R., 1964. Statystyka matematyczna w zastosowaniu doświadczalnictwa rolniczego. PWN, Warszawa.

Es a u K., 1973. Anatomia roślin, FWRiL, Warszawa, transl. from Plant anatomy 2-nd ed. J. Wiley, New York, 1965.

F a deeva T. S., 1975. Genetika zemlyaniki, Izd. Lenigr. Univ. Leningrad.

Grainger J., 1956. The economic effects of crop disease. The West of Scotland Agricultural College Research Bulletin, 16: 21-23.

$\mathrm{Havis}$ A. L., 1940. A developmental analysis of kohlrabi and cabbage stems. Jour. Agric. Res., 61: 459-470.

Havis A. L., 1943. A developmental analysis of the strawberry fruit. Amer. Jour. Bot., 30: 311-314.

Houghtaling H. B., 1935. A developmental analysis of size and shape in tomato fruits. Bull. Torrey Club, 62: 243-252.

Jensen W. A., 1962. Botanical Histochemistry, Freeman C. O. San Francisco.

Łucka M., 1967. Uprawa krzewów jagodowych, PWRL, Warszawa.

II a c Arthur M., Wetmore R. H., 1941. Developmental studies of the apple 
fruit in the varieties McIntosh Red and Wagner. II An analysis of development. Canad. Jour. Res. C., 19: 371-382.

Ma c Daniels L. H., 1940. The morphology of the apple and other pome fruits B. Y. (Cornell) Agr. Exp. Sta. Mem., 230: 3-33.

Marzec T., Purtak M., Przygodzka I., 1962. Truskawki i maliny. Wyd. Czas. Tech. NOT. Warszawa.

Ne a I G. E., 1964. Changes occurring in the walls of strawberries during ripening. J. Sci. Fd. Agric., 16: 604-611.

Pieniażek S. A., 1976. Sadownictwo. Wyd. VI, PWRiL, Warszawa.

Sinnott E. W., 1936. The relation of organ size to tissue development in the stem. Amer. Bot, 23: 602-606.

Sinnott E. W., 1939. A developmental analysis of the relation between cell size and fruit size in cucurbites. Amer. Bot., 26: 179-189.

Smock R. M., Neubert A. M., 1950. Apples and apple products Interscience Publ. Inc. New York.

Stebbins G. L., 1958. Zmienność i ewolucja roślin. PWN, Warszawa.

Tukey L. D., 1974. Some relations in the growth and development of apple fruits. Proc. XIX Inter. Hort. Congress, 3: 35-45.

White P. R., 1927. Studies of the physiological anatomy of the strawberry. Jour. Agr. Res., 35: 481-492.

Z. a łęska Z., 1964. Badania anatomiczne nad owocnią ogórka Cucumis sativus L. Acta agrobot., 16: 87-104.

Badania anatomiczne dna kwiatowego truskawki (Fragaria grandiflora Ehrh.) w początkowych stadiach rozwoju

\section{Streszczenie}

Badano zmiany anatomiczne w owocu truskawki w czasie jego wzrostu. Kwiaty lub owoce brano z wierzchołków kwiatostanów z roślin odmiany 'Talizman', uprawianej $w$ szklarni przy dlugim dniu. Opracowano metode zatapiania dna kwiatowego truskawki w mieszaninie parafiny, gumy i wosku. W kwiecie truskawksi wyróżniono 3 różne układy wiązek waskularnych zaopatrujące poszczególne części kwiatu. Najsilniejszy wzrost średniej liczby komórek następuje w korze. Liczba komórek rdzenia począwszy od piątego dnia po zapyleniu prawie nie przyrastała. Między 5 a 10 dniem po zapyleniu nie przyrastała także liczba komórek kory w wierzcholkowej części owocu. 